\title{
Chapter 2 \\ COVID-19 Pandemic and Behavioural Change: The Cases of Florida and Ohio
}

\author{
Makoto Yano
}

\begin{abstract}
This study investigates the influences of COVID-19 spread at an early stage of the pandemic by focusing the cases in Florida and Ohio. Evidence is provided indicating that if the messages delivered by the national leadership and the local leadership are unified and coordinated with each other (as in Florida), they have a significant impact on the public's behavoural change or its self-protection effort. Moreover, social learning appears to contribute to effecitve self-protection efforts of the public. These effects are not observed in a state in which mixed messages are sent by the national and local government (Ohio).
\end{abstract}

Keywords COVID-19 outbreak $\cdot$ Political factors $\cdot$ Social learning

\section{Introduction}

By now, it has become clear that behavioural change - starting to wear a mask and keeping a social distance-is one of the most important keys to fight the COVID19 outbreak. As the outbreak enlarges, we see that people's readiness for such behavioural change depends on various socio-life scientific factors: Epidemiological, political scientific, economic, sociological, behavioural, among others. The present study investigates the roles of these factors by focusing on a very early stage of the pandemic (mid-April, 2020) in the US state of Florida; this focus is set to capture the pure effects of those factors without unnecessary noises. Data on 67 counties is used. Our results support the existence of a natural epidemiological factor in the

This chapter is a much revised version of the discussion paper with the same title (RIETI DP 2020 E 040). It is a product of a research project at the Research Institute of Economy, Trade and Industry (RIETI) titled "Evidence-based Policy Study on the Law and Economics of Market Quality", organized by Yuichi Furukawa. I am grateful to Jeff Nugent, Peter Rosendorff, Masato Yodo, Masahiko Nakazawa, Rui Ota, Shigeru Hirota, Masahiro Sato, and Takakazu Honryo for useful comments on the DP and conversatios. The author gratefully acknowledges partial financial support from the Grant-in-Aid for Scientific Research (A) \#16H02015.

M. Yano (凶)

Research Institute of Economy, Trade and Industry, Tokyo, Japan

e-mail: yano-makoto@ rieti.go.jp

M. Yano et al. (eds.), Socio-Life Science and the COVID-19 Outbreak, Economics, Law, and Institutions in Asia Pacific, https://doi.org/10.1007/978-981-16-5727-6_2 
way the disease spread and the importance of political leadership in containing the pandemic. Some evidence is found that suggests the positive role of social learning in guiding people to make behavioural change towards self-protection.

There are several reasons why we focus on Florida. One is that Florida is a big peninsula mostly surrounded by the sea; only the northern border is connected to other states. Moreover, the population is spread over the state with population centers at Miami (population, 5,502,400) on the southeast coast of the peninsula, Tampa $(2,441,900)$ on the middle west coast, and Orlando $(1,510,600)$ in the center. These geographical features are desirable to detect the natural factors that might be at work in the spread of the virus.

Another reason is that Florida offers a good proxy representing the role of political leadership. The more transparent information is, the better the decision. Despite this, however, President Trump downplayed the danger of, and overstated the government's capability of handling, the outbreak of COVID-19 through the middle of March 2020. ${ }^{1}$ The governor of Florida, Ron DeSantis, strongly supported the president's view. If people were more readily to believe the overly-optimistic messages from these leaders, they would tend to underprepare against the outbreak, thereby increasing the likelihood of catching the virus and spreading it to others. By investigating this scenario, we capture the role of political leadership.

This study tries to capture the social learning factor of people by the population density and number of cities of a particular region. ${ }^{2}$ By mid-April 2020, it was clear that the instances of COVID-19 were worse in more populated urban regions on the northeast coast of the US, including New York, New Jersey, and Connecticut. If people learned from those experiences, those who lived in an urban region with a higher population density would be more careful and more readily change their behaviour to protect themselves against the virus. If so, the pandemic should spread less in a more populated urban region, thereby evidencing the presence of a social learning factor towards self-protection.

Our results show that the more core supporters of President Trump in a region, the larger number per capita of COVID-19 cases in Florida, which suggests the importance of political messages that a leader delivers in the fight against the pandemic. The more populated a region is, the smaller number per capita of COVID-19 cases. This effect is clearer if county population is adjusted by an urbanization factor of county. Except for the seven most populated counties, the more urban a county is, the smaller the number per capita of COVID-19 cases. For the seven most populated counties, the more urban a region is, the larger the number per capita. These results suggest that social learning towards self-protection takes place in more populated and more urban areas. However, if a county has too large a population, the self-protection effort is not enough effectively to fight against the virus.

Finally, the number of cases accelerates more quickly with the population of a region. This is consistent with the nature of virus transmission.

\footnotetext{
${ }^{1}$ For example, see a Washington Post article by Blake (2020), which timelines Trump's early remarks on the outbreak.

${ }^{2}$ Sato et al. (2020).
} 
These results are likely to be special features of Florida, which is relatively isolated from other populated regions. To confirm this, I conduct similar tests for the state of Ohio, which has similar political features, and find that no relationship exists between the number per capita of COVID-19 cases and various potential determinants.

\section{Results}

We capture the effect of local and national politics by the behaviour of core Trump supporters, which we represent by the ratio between the number of votes for the Republican Trump-supporting governor in the 2018 election and that for the president in the 2016 election, or

$$
R=\frac{\# \text { Votes for the Republican candidata in the } 2018 \text { Gubernatorial election }}{\# \text { Votes for President Trump in the } 2016 \text { election }}
$$

This choice of a proxy can be explained as follows: Florida is well known as a swing state, in which Republican and Democratic candidates have divided the total votes almost evenly between them in many past elections. In 2016, people voted for President Trump rather decisively. In 2018, Florida elected a new governor, Governor DeSantis, who has been widely regarded as a disciple of President Trump. ${ }^{3} \mathrm{He}$ has followed closely the policy taken by Trump. In 2018, as is well known, the president significantly lost popularity due to many scandals; the Republicans lost large numbers of seats nationwide in the 2018 election. From these facts, we may assume that the voters for Governor DeSantis in 2018 election were likely to be strong supporters for President Trump; in other words, the number of votes for Governor DeSantis in 2018 should closely be correlated to that of votes for President Trump in the 2016 election. minus the number of voters who decided no longer to support the president in 2018 election. For this reason, we assume that the ratio in a county between the number of votes for Governor DeSantis and that for President Trump captures the relative side of core Trump supporters in that county, which we call the leader index. Over the Florida counties, the index is distributed between 0.73 and 0.98 .

This study conduct OLS (ordinary least squares) estimations to test a number of models that may explain the number per capita of COVID-19 cases by different explanatory variables. In those explanatory variables, the leader index may suffer from the endogeneity problem. In an election, people tend to vote for the candidate with whom they share personal philosophy; it is natural that the same personal philosophy influences how a person acts against the pandemic. As a result, the number of coronavirus cases and the governor/president ratio can be endogenously determined.

\footnotetext{
${ }^{3}$ In his Guardian article, Luscombe (2020) introduces the governor as a self-confessed Trump disciple (and often referred to as a "mini-Trump"). Also see Nazaryan (2020).
} 
To deal with this problem, the present study conducts instrumental variable estimations after deciding the best fit model specification by OLS. As the instrumental variable, we adopt the county property tax, which may be positively correlated to the leader index. Because the county property tax is pre-determined way before the current COVID-19 outbreak, it is impossible that the number per capita of COVID-19 cases influences the county property tax. Moreover, it is highly unlikely that there is a direct channel through which the property tax influences the number per capita of COVID-19 cases. For these reasons, the property tax rate can be a good candidate for an instrument for the core Trump supporter index to explain the number per capita of COVID-19 cases.

Our findings may be summarized as follows.

Observation 1 In Florida, where the local leader followed the national leader by downplaying the danger of the virus at an early stage of the outbreak:

(1) the spread of the coronavirus accelerates with population,

(2) the larger the number of core Trump voters, the worse the spread of the virus,

(3) except for the seven most populated counties, the coronavirus cases per capita decrease with urbanization, and

(4) many economic factors have little effects on the spread of the virus.

It is highly likely that these results reflect unique features of Florida. To double check this possibility, we examine the cases in Ohio, which shares several crucial political characteristics. None of the above results are observed in Ohio data.

\section{Literature}

There are a number of studies that, like this study, focus on the early development of the pandemic. Here, I will explain only those studies; this study contributes to the literature that is concerned with political factors as a determinant of the outbreak. Bursztyn et al. (2020) investigate the effect of misinformation on the spread of a pandemic. They focus on two Fox News shows and demonstrate that greater viewership of the more pro-Trump show (Hannity) is associated with more COVID-19 cases and deaths in the early stages of the pandemic. Both this and their studies are based on Johns Hopkins data.

The rest of the literature that is concerned with the effectiveness of social distancing. Ajzenman et al. (2020) investigate the effect on social distancing of the Brazilian president's dismissal of the coronavirus risk. They show that his dismissal reduced social distancing more in pro-government localities, captured by geo-localized mobile phone data. Adolph et al. (2020) show that Republican governors and governors from states with more Trump supporters were slower to adopt social distancing policies. Allcott et al. (2020) report significant gaps between Republicans and Democrats in beliefs about personal risk, which may influence the future path of the pandemic. Barrios and Hockberg (2020) show that as Trump vote share 
rises, individuals search less for information on the virus and unemployment benefits and reduce less both their daily distance traveled and their visits to non-essential businesses. Anderson (2020) shows that mandatory measures on social distancing may have been effective at reducing the frequency of visits to locations outside of one's home. Brzezinski et al. (2020) show that individuals skeptical about the human causes of climate change are less likely to comply with social distancing regardless of their political views.

More broadly, this study is related to several studies that treat the epidemiology of the coronavirus pandemic from the social scientific viewpoint. By using internet data, Fetzer et al. (2020) document a rapid surge in economic anxieties after the arrival of the coronavirus in the US and substantial heterogeneity in participants' beliefs about mortality from and the contagiousness of the virus. Using county data on population movement derived from cell phone location data, Wright et al. (2020) build a theoretical model that shows that poverty and negative economic shocks from the US trade war will reduce compliance with social distancing.

There is a large volume of empirical studies that capture the effect of misinformation by media. For studies in that literature, see Bursztyn et al. (2020).

\section{Data}

We use only publicly available data. The data source for coronavirus cases is from the Johns Hopkins University Coronavirus Resource Center at https://coronavirus. jhu.edu/us-map/, which is the same as Bursztyn et al. (2020). Every day, this site refreshes, and updates, the numbers of cases and deaths in each US county. Our estimation is based on April 15, 2020, data for Florida and April 20, 2020, data for Ohio.

In addition to the leader index, $R$, the main explanatory variables include population, area and the number of cities, which are regarded as exogenous variables in our estimation equations. Many other explanatory variables are included as control and instrumental variables. They are: urban and rural population density, water area, per capital income, education, wage, median home value, average property tax, poverty rate, and the number of hospitals. We will come back to the choice of instrumental variables in Sect. 4.4.

In place of descriptive statistics, we present the plots of vectors of main variables; the left-hand side panels are on Florida whereas the right-hand side panels are on Ohio. Figure 1 shows that in each data set one outlier exists. For Florida, MiamiDade County, where Miami is located, has both a large number of coronavirus cases and a large population. For Ohio, the outlier is Marion county, in which more than 1000 people contracted the virus at a state prison. As is shown below, the existence of these outliers has little effect on our estimation results.

All election data is from the New York Times site. Florida population estimates for 2019 are from the Office of Economic and Demographic Research of the Florida 
(a) Florida Cases against Population

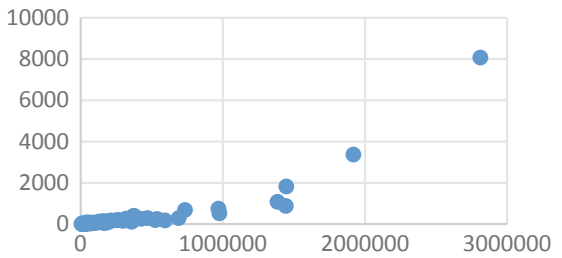

(b) Florida Cases against Income

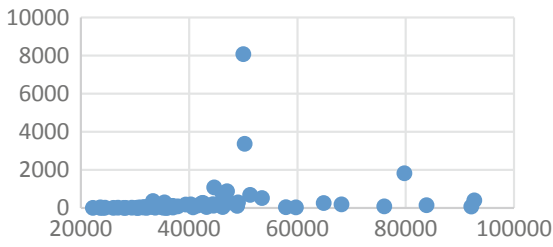

(c) Florida Cases against Median Age

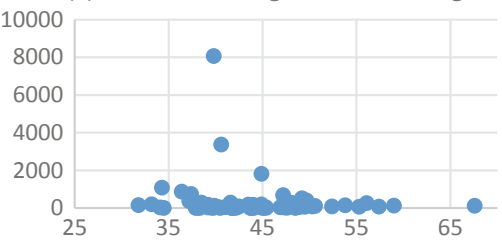

(d) Florida Cases against GP Ratio

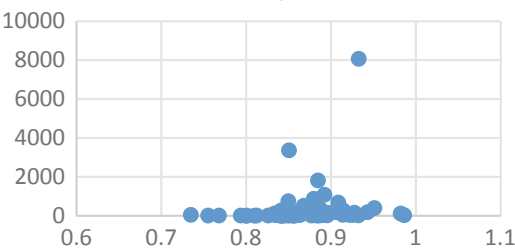

(e) Florida Income against Age

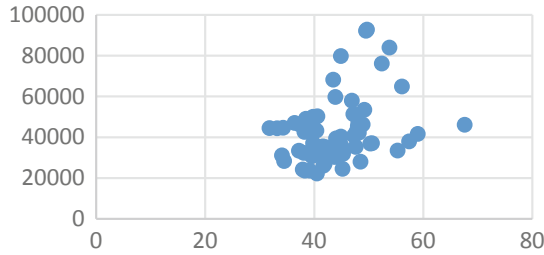

(f) Ohio Cases against Population

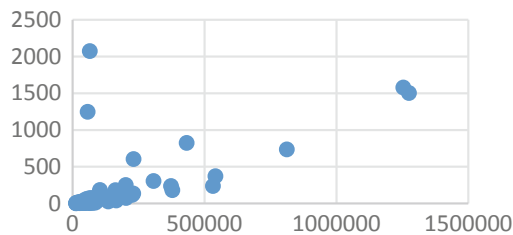

(g) Ohio Cases against Income

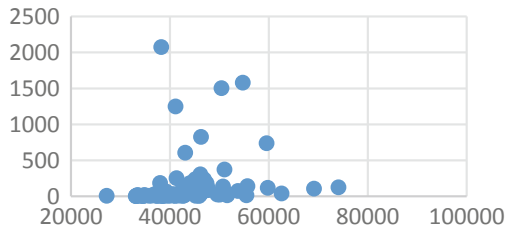

(h) Ohio Cases against Median Age

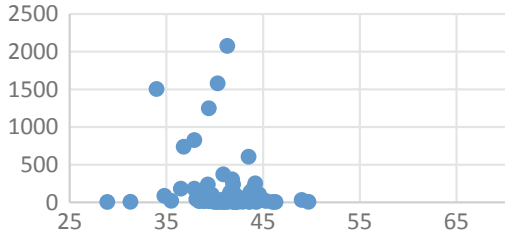

(i) Ohio Cases against the GP ratio

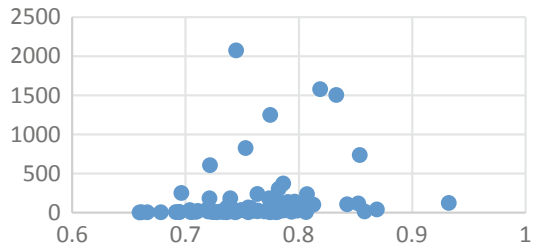

(j) Ohio Income against Age

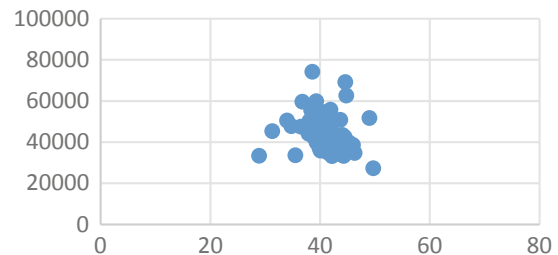

Fig. 1 Descriptive statistics

Legislature. ${ }^{4}$ Ohio population estimates are from Ohio Demographics at the Cubit site. ${ }^{5}$ County area data is from the site of Florida Association of Counties for Florida

\footnotetext{
${ }^{4}$ http://edr.state.fl.us/Content/population-demographics/data/index-floridaproducts.cfm. 5 www.ohio-demographics.com/counties_by_population.
} 
and from the USA.com site for Ohio. ${ }^{6}$ Data on the number of cities is from the Florida Association of Counties site for Florida and from Wikipedia (list of cities in Ohio) for Ohio. ${ }^{7}$ Data for instrumental variables are from the following sites. Education data from the Town Charts. ${ }^{8}$ Median home value and average property tax data for Florida from the Smart Asset site. ${ }^{9}$ Data for control variables are from the following sites. Median home value data for Ohio from the Cleveland.com site. ${ }^{10}$ Urban and rural population density data from 2010 Census Urban and Rural Classification and Urban Area Criteria. ${ }^{11}$ Florida water area data from the USA.com site. ${ }^{12}$ Per capita income data from the US Department of Commerce, Bureau of Economic Analysis (2018). ${ }^{13}$ Wage rate data from the US Bureau of Labor Statistics site. ${ }^{14}$ Poverty data from Sandoval (2015, percentage of poor) for Florida and from the Index Mundi site for Ohio. ${ }^{15}$ Data on the number of hospitals from Wikipedia. ${ }^{16}$

\section{Possible Determinants of the COVID-19 Spread}

\subsection{Acceleration Effect of Population}

To capture the determinant of the COVID-19 spread, we estimate several different models. The first is the single explanatory variable model. That is, we estimate the number per capita of COVID-19 cases on one of the demographic and economic factors considered here, that is, population, population density, the number of cities in a county, per capita income, education level, median-home value, wage rate, the area of a county, the number of hospitals, and poverty level. The estimation equation is.

\footnotetext{
${ }^{6}$ www.fl-counties.com/county-population-and-general-information and www.usa.com/rank/ohiostate--land-area--county-rank.htm.

7 www.fl-counties.com/florida-cities-county and https://en.wikipedia.org/wiki/List_of_cities_in_ Ohio.

${ }^{8}$ www.towncharts.com/United-States-Education-data.html.

${ }^{9} \mathrm{https} / / /$ smartasset.com/taxes/florida-property-tax-calculator.

${ }^{10}$ www.cleveland.com/datacentral/2017/12/ranking_every_ohio_city_county_9. html.

${ }^{11}$ www.census.gov/programs-surveys/geography/guidance/geo-areas/urban-rural/2010-urbanrural.html.

12 www.usa.com/rank/florida-state--water-area--county-rank.htm?yr=9000\&dis $=\&$ wist $=\&$ plow $=\&$ phigh $=$

${ }^{13}$ www.bea.gov/data/income-saving/personal-income-county-metro-and-other-areas.

${ }^{14}$ www.bls.gov/regions/southeast/news-release/countyemploymentandwages_florida.htm.

15 www.indexmundi.com/facts/united-states/quick-facts/ohio/percent-of-people-of-all-ages-inpoverty\#table.

${ }^{16}$ List of hospitals in Florida and in Ohio: https://en.wikipedia.org/wiki/List_of_hospitals_in_Flo rida and https://en.wikipedia.org/wiki/List_of_hospitals_in_Ohio, downloaded in May 2020.
} 


$$
n=c+\beta_{o}[\text { one social factor }] \text {, }
$$

where the dependent variable is the number of COVID-19 cases per capita in a county, $n=N / P$, where $N$ and $P$ are the number of cases in county and the population of the county, respectively.

Table 1a summarizes the estimation results. This shows that the number per capita of COVID-19 cases are significantly correlated to the socio-economic factors considered in this study. Many of these correlations are, however, absorbed by population.

That is, once we include population in addition to one of the factors, the correlation with the latter factor disappears. That is, we estimate

$$
n=c+\beta_{P} P+\beta_{o}[\text { another explanatory factor }]
$$

Table 1a Factors contributing to the outbreak in an early stage in Florida. Dependent variable: Per

\begin{tabular}{|c|c|c|c|c|c|c|c|c|c|}
\hline \multicolumn{4}{|l|}{1} & \multicolumn{4}{|l|}{2} & \multicolumn{2}{|l|}{3} \\
\hline Constant & \multicolumn{3}{|c|}{$\begin{array}{l}0.0004 * * * \\
(7.83)\end{array}$} & \multicolumn{2}{|c|}{ Constant } & \multicolumn{2}{|c|}{$\begin{array}{l}0.0005^{* * *} \\
(7.62)\end{array}$} & Constant & $\begin{array}{l}0.0004 \\
(6.26)\end{array}$ \\
\hline Population & \multicolumn{3}{|c|}{$\begin{array}{l}5.83 \mathrm{E}-10 * * * \\
(6.54)\end{array}$} & \multicolumn{2}{|c|}{$\begin{array}{l}\text { Population } \\
\text { density }\end{array}$} & \multicolumn{2}{|c|}{$2.66 \mathrm{E}-7 * * *$} & $\begin{array}{l}\text { Number of } \\
\text { cities }\end{array}$ & $2.92 \mathrm{E}-5^{* * *}$ \\
\hline $\mathrm{R} 2$ & \multicolumn{3}{|l|}{0.4} & \multicolumn{2}{|l|}{$\mathrm{R} 2$} & \multicolumn{2}{|l|}{0.12} & R2 & 0.22 \\
\hline \multicolumn{4}{|l|}{4} & \multicolumn{4}{|l|}{5} & \multicolumn{2}{|l|}{6} \\
\hline \multicolumn{2}{|l|}{ Constant } & \multicolumn{2}{|c|}{$\begin{array}{l}0.0002 \\
(1.03)\end{array}$} & \multicolumn{2}{|c|}{ Constant } & \multicolumn{2}{|l|}{$\begin{array}{l}0.0002 \\
(1.55)\end{array}$} & Constant & $\begin{array}{l}0.0002 \\
(1.31)\end{array}$ \\
\hline \multicolumn{2}{|c|}{ Income per capita } & \multicolumn{2}{|c|}{$\begin{array}{l}1.03 \mathrm{E}-8 * * * \\
(4.28)\end{array}$} & \multicolumn{2}{|c|}{ Education } & \multicolumn{2}{|c|}{$\begin{array}{l}1.83 \mathrm{E}-5 * * * \\
(3.26)\end{array}$} & $\begin{array}{l}\text { Home value } \\
\text { (Median) }\end{array}$ & $\begin{array}{l}2.90 \mathrm{E}-9 * * * \\
(3.65)\end{array}$ \\
\hline \multicolumn{2}{|l|}{ R2 } & \multicolumn{2}{|l|}{0.12} & \multicolumn{2}{|c|}{ R2 } & 0.14 & & R2 & 0.17 \\
\hline \multicolumn{3}{|l|}{7} & \multicolumn{4}{|l|}{8} & \multicolumn{3}{|l|}{9} \\
\hline Constant & \multicolumn{2}{|c|}{$\begin{array}{l}-0.0003 \\
(-1.20)\end{array}$} & & nstant & $\begin{array}{r}0.000 \\
(1.97)\end{array}$ & & Cons & $\tan t$ & $\begin{array}{l}0.0004 * * * \\
(7.02)\end{array}$ \\
\hline Wage & $\begin{array}{l}1.23 \mathrm{E} \\
(3.34)\end{array}$ & $-6^{* * * *}$ & $\mathrm{Ar}$ & & $\begin{array}{r}4.42 \mathrm{E} \\
(3.12)\end{array}$ & $E-7 * * *$ & Hosp & itals (number) & $\begin{array}{l}0.0000 * * * \\
(5.25)\end{array}$ \\
\hline $\mathrm{R} 2$ & 0.15 & & $\mathrm{R} 2$ & & 0.12 & & R2 & & 0.3 \\
\hline 10 & & & & & & & & & \\
\hline Constant & & $\begin{array}{r}0.00 \\
(7.02\end{array}$ & & & & & & & \\
\hline Poverty & & $\begin{array}{r}0.00 \\
(5.25\end{array}$ & & & & & & & \\
\hline R2 & & 0.3 & & & & & & & \\
\hline
\end{tabular}
capita cases in Florida counties (\# of observation $=67$ )

The values in () are $t$ values (***,**, and * for $1 \%$ significance, $5 \%$ significance and $10 \%$ significance, respectively) 
The estimation results are summarized in Table $1 \mathrm{~b}$. The table shows that once population is included in the estimation, most of the other explanatory variables become insignificant except for population density and the leader index.

In all estimation results, the number of per capita cases is positively correlated to population. This implies, by $n=N / P$, that column 1 in Table 1a, for example, gives rise to

Table 1b Factors contributing to the outbreak in an early stage in Florida:. Joint effects with population. Dependent variable: Per capita cases in Florida counties (\# of observation $=67$ )

\begin{tabular}{|c|c|c|c|c|c|c|}
\hline \multicolumn{3}{|l|}{1} & \multicolumn{2}{|l|}{2} & \multicolumn{2}{|l|}{3} \\
\hline Constant & \multicolumn{2}{|c|}{$\begin{array}{l}0.0004 * * * \\
(8.28)\end{array}$} & Constant & $\begin{array}{l}0.0005 * * * \\
(7.31)\end{array}$ & Constant & $\begin{array}{l}0.0004 * \\
(1.7)\end{array}$ \\
\hline \multirow[t]{2}{*}{ Population } & \multicolumn{2}{|c|}{$\begin{array}{l}5.83 \mathrm{E}-10^{* * * *} \\
(6.54)\end{array}$} & Population & $\begin{array}{l}7.7 \mathrm{E}-10 * * * \\
(3.4)\end{array}$ & Population & $\begin{array}{l}6.4 \mathrm{E}-10^{* * *} \\
(4.4)\end{array}$ \\
\hline & & & $\begin{array}{l}\text { Population } \\
\text { density }\end{array}$ & $\begin{array}{l}-2.28 \mathrm{E}-7 * * \\
(-2.05)\end{array}$ & $\begin{array}{l}\text { Number of } \\
\text { cities }\end{array}$ & $\begin{array}{l}-4.8 \mathrm{E}-6 \\
(-0.49)\end{array}$ \\
\hline $\mathrm{R} 2$ & \multicolumn{2}{|l|}{0.4} & $\mathrm{R} 2$ & 0.44 & R2 & 0.40 \\
\hline \multicolumn{3}{|l|}{4} & \multicolumn{2}{|l|}{5} & \multicolumn{2}{|l|}{6} \\
\hline Constant & \multicolumn{2}{|c|}{$\begin{array}{l}0.0002 * * * \\
(3.0)\end{array}$} & Constant & $\begin{array}{l}0.0003^{* *} \\
(2.17)\end{array}$ & Constant & $\begin{array}{l}0.0002 * * \\
(1.61)\end{array}$ \\
\hline Population & \multicolumn{2}{|c|}{$\begin{array}{l}5.35 \mathrm{E}-10 * * * \\
(5.79)\end{array}$} & Population & $\begin{array}{l}5.5 \mathrm{E}-10^{* * * *} \\
(5.29)\end{array}$ & Population & $\begin{array}{l}5.1 \mathrm{E}-10 * * * \\
(5.43)\end{array}$ \\
\hline $\begin{array}{l}\text { Income per } \\
\text { capita }\end{array}$ & \multicolumn{2}{|c|}{$\begin{array}{l}5.0 \mathrm{E}-9 * \\
(1.7))\end{array}$} & Education & $\begin{array}{l}4.0 \mathrm{E}-6 \\
(0.74)\end{array}$ & $\begin{array}{l}\text { Home value } \\
\text { (Median) }\end{array}$ & $\begin{array}{l}1.4 \mathrm{E}-9 * \\
(1.9)\end{array}$ \\
\hline $\mathrm{R} 2$ & \multicolumn{2}{|l|}{0.43} & $\mathrm{R} 2$ & 0.41 & R2 & 0.43 \\
\hline \multicolumn{3}{|l|}{7} & \multicolumn{2}{|l|}{8} & \multicolumn{2}{|l|}{9} \\
\hline Constant & \multicolumn{2}{|l|}{$\begin{array}{l}0.0005 \\
(-1.20)\end{array}$} & Constant & $\begin{array}{l}0.0004 * * * * \\
(1.97)\end{array}$ & Constant & $\begin{array}{l}0.0004 * * * \\
(7.02)\end{array}$ \\
\hline Population & \multicolumn{2}{|c|}{$\begin{array}{l}6.0 \mathrm{E}-10 * * * \\
(5.15)\end{array}$} & Population & $\begin{array}{l}5.6 \mathrm{E}-10 * * * \\
(5.34)\end{array}$ & Population & $\begin{array}{l}9.1 \mathrm{E}-10 * * * \\
(3.62)\end{array}$ \\
\hline Wage & \multicolumn{2}{|c|}{$\begin{array}{l}-7.3 \mathrm{E}-8 \\
(-0.18)\end{array}$} & Area & $\begin{array}{l}6.0 \mathrm{E}-8 \\
(0.43)\end{array}$ & $\begin{array}{l}\text { Hospitals } \\
\text { (number) }\end{array}$ & $\begin{array}{l}-3.4 \mathrm{E}-5 \\
(-1.4)\end{array}$ \\
\hline $\mathrm{R} 2$ & 0.40 & & $\mathrm{R} 2$ & 0.40 & $\mathrm{R} 2$ & 0.42 \\
\hline 10 & & & & & & \\
\hline Constant & & $\begin{array}{r}0.000 \\
(7.02)\end{array}$ & $4 * * *$ & & & \\
\hline Population & & $\begin{array}{r}9.1 \mathrm{E} \\
(3.62)\end{array}$ & $-10 * * *$ & & & \\
\hline Poverty & & $\begin{array}{l}-3.4 \mathrm{E} \\
(-1.4)\end{array}$ & & & & \\
\hline $\mathrm{R} 2$ & & 0.42 & & & & \\
\hline
\end{tabular}

The values in () are $t$ values $(* * *, * *$, and $*$ for $1 \%$ significance, $5 \%$ significance and $10 \%$ significance, respectively) 


$$
N_{j}=41.5\left(\frac{P_{j}}{10^{5}}\right)+5.8\left(\frac{P_{j}}{10^{5}}\right)^{2}
$$

This shows that, as population increases, the coronavirus cases increase with an acceleration rate of 11.6 people per 10,000 people. All the other estimations show that the coefficient on $P^{2}$ is significant, mostly at the $1 \%$ level and positive. This is consistent with the theoretical prediction that if people would believe leaders who downplay the danger of an epidemic, the epidemic would spread in a natural manner. In the literature on epidemiology, it has been established that the spread of the outbreak accelerates with population at its early stage (see Kermack and McKendrick (1927)).

Finding 1 In Florida, the spread of COVID-19 cases accelerates with county population at an acceleration rate between 9 and 14 per 10,000 people with/without control variables included.

\subsection{Pandemic Suppressing Effect of Population Density}

See Table 1b. An important finding in the previous model, (3), is that the significant effects of population density $D$ and the leader index $R$, defined by (1). Section 2 . That is, leader index $R$ is positively correlated to the number per capita of COVID19 cases. This suggests that the presence of core Trump supporters worsens the contagion.

Even more interesting is the finding that population density is negatively correlated to the number per capital of cases. As is discussed in the Introduction, if people realized that COVID-19 spreads more readily in a more populated area, they might put more self-protective efforts. Our finding is consistent with this possibility.

With these considerations, in this section, we add population density $D$ and leader index $R$ in our estimation equation, which is

$$
n=c+D+R+\beta_{P} P+\beta_{o}[\text { another explanatory factor }] \text {. }
$$

Table 1c summarizes the results. An important finding is that once population, population density and the president/governor ratio are controlled, each of the other explanatory variables loses explanatory power completely. This suggests that model (5) fits our data better than models (2) and (3). At the same time, the effect of the leader index remains significant and positive.

The effect of population density remains significant and negative. This sharply contrasts with the common intuition that, as population density increases, the chance of contracting an epidemic would become higher.

One possible reason might be that population density (population per square mile) may not capture how crowded a particular region actually is. With this consideration, 
Table 1c Factors contributing to the outbreak in an early stage in Florida: Joint effects with population, population density, and G/P ratio. Dependent variable: Per capita cases in Florida counties (\# of observation = 67)

\begin{tabular}{|c|c|c|c|c|c|}
\hline \multicolumn{2}{|c|}{1} & \multicolumn{2}{|l|}{2} & \multicolumn{2}{|l|}{3} \\
\hline Constant & $\begin{array}{l}-0.0021^{* * *} \\
(-2.86)\end{array}$ & Constant & $\begin{array}{l}-0.0022 * * * \\
(-2.92)\end{array}$ & Constant & $\begin{array}{l}-0.0022 * * * \\
(-2.87)\end{array}$ \\
\hline \multirow[t]{2}{*}{ Population } & $\begin{array}{l}5.24 \mathrm{E}-10 * * * \\
(6.24)\end{array}$ & Population & $\begin{array}{l}7.2 \mathrm{E}-10 * * * \\
(6.09)\end{array}$ & Population & $\begin{array}{l}7.1 \mathrm{E}-10^{* * * *} \\
(4.48)\end{array}$ \\
\hline & & $\begin{array}{l}\text { Population } \\
\text { density }\end{array}$ & $\begin{array}{l}-2.29 \mathrm{E}-7 * * \\
(-2.26)\end{array}$ & $\begin{array}{l}\text { Population } \\
\text { density }\end{array}$ & $\begin{array}{l}-2.29 \mathrm{E}-7 * * \\
(-2.9)\end{array}$ \\
\hline \multirow[t]{2}{*}{$\mathrm{G} / \mathrm{P}$ ratio } & $\begin{array}{l}0.0030 * * * \\
(3.41)\end{array}$ & G/P ratio & $\begin{array}{l}0.0030 * * * \\
(3.53)\end{array}$ & $\mathrm{G} / \mathrm{P}$ ratio & $\begin{array}{l}0.0027 * * * \\
(3.47)\end{array}$ \\
\hline & & & & $\begin{array}{l}\text { Number of } \\
\text { cities }\end{array}$ & $\begin{array}{l}5.55 \mathrm{E}-7 \\
(0.06)\end{array}$ \\
\hline R2 & 0.49 & R2 & 0.53 & $\mathrm{R} 2$ & 0.53 \\
\hline \multicolumn{2}{|l|}{4} & \multicolumn{2}{|l|}{5} & \multicolumn{2}{|l|}{6} \\
\hline Constant & $\begin{array}{l}0.0020^{* * * *} \\
(-2.6)\end{array}$ & Constant & $\begin{array}{l}-0.0022^{* *} \\
(-2.73)\end{array}$ & Constant & $\begin{array}{l}-0.0020^{* * *} \\
(-2.63)\end{array}$ \\
\hline Population & $\begin{array}{l}7.1 \mathrm{E}-10^{* * * *} \\
(5.96)\end{array}$ & Population & $\begin{array}{l}7.2 \mathrm{E}-10^{* * * *} \\
(6.01)\end{array}$ & Population & $\begin{array}{l}6.9 \mathrm{E}-10^{* * * *} \\
(5.67)\end{array}$ \\
\hline $\begin{array}{l}\text { Population } \\
\text { density }\end{array}$ & $\begin{array}{l}-2.37 \mathrm{E}-7 * * \\
(-2.32)\end{array}$ & $\begin{array}{l}\text { Population } \\
\text { density }\end{array}$ & $\begin{array}{l}-2.25 \mathrm{E}-7^{* * *} \\
(-2.1)\end{array}$ & $\begin{array}{l}\text { Population } \\
\text { density }\end{array}$ & $\begin{array}{l}-2.31 \mathrm{E}-7 * * \\
(-2.27)\end{array}$ \\
\hline $\mathrm{G} / \mathrm{P}$ ratio & $\begin{array}{l}0.0031 * * * \\
(2.93)\end{array}$ & $\mathrm{G} / \mathrm{P}$ ratio & $\begin{array}{l}0.0027 * * * \\
(3.13)\end{array}$ & $\mathrm{G} / \mathrm{P}$ ratio & $\begin{array}{l}0.0032 * * * \\
(3)\end{array}$ \\
\hline $\begin{array}{l}\text { Income per } \\
\text { capita }\end{array}$ & $\begin{array}{l}2.22 \mathrm{E}-9 \\
(0.75))\end{array}$ & Education & $\begin{array}{l}-8.220 \mathrm{E}-7 \\
(-0.15)\end{array}$ & $\begin{array}{l}\text { Home Value } \\
\text { (Median) }\end{array}$ & $\begin{array}{l}7.06 \mathrm{E}-10 * \\
(1.01)\end{array}$ \\
\hline R2 & 0.53 & $\mathrm{R} 2$ & 0.53 & R2 & 0.54 \\
\hline \multicolumn{2}{|c|}{7} & \multicolumn{2}{|c|}{8} & \multicolumn{2}{|l|}{9} \\
\hline Constant & $\begin{array}{l}-0.0019 * * \\
(-2.38)\end{array}$ & Constant & $\begin{array}{l}-0.0021 * * * \\
(-2.81)\end{array}$ & Constant & $\begin{array}{l}-0.0022 * * * \\
(-2.86)\end{array}$ \\
\hline Population & $\begin{array}{l}7.9 \mathrm{E}-10^{* * * *} \\
(5.8)\end{array}$ & Population & $\begin{array}{l}8.3 \mathrm{E}-10 * * * \\
(5.13)\end{array}$ & Population & \begin{tabular}{|l}
$7.0 \mathrm{E}-10^{* * * *}$ \\
$(2.96)$
\end{tabular} \\
\hline $\begin{array}{l}\text { Population } \\
\text { density }\end{array}$ & $\begin{array}{l}-1.96 \mathrm{E}-7^{*} \\
(-1.85)\end{array}$ & $\begin{array}{l}\text { Population } \\
\text { density }\end{array}$ & $\begin{array}{l}-2.95 \mathrm{E}-7^{* * *} \\
(-2.45)\end{array}$ & $\begin{array}{l}\text { Population } \\
\text { density }\end{array}$ & $\begin{array}{l}-2.33 \mathrm{E}-7^{*} \\
(-1.99)\end{array}$ \\
\hline $\mathrm{G} / \mathrm{P}$ ratio & $\begin{array}{l}0.0032 * * * \\
(3.68)\end{array}$ & $\mathrm{G} / \mathrm{P}$ ratio & $\begin{array}{l}0.0031 * * * \\
(3.57)\end{array}$ & G/P ratio & $\begin{array}{l}0.0030^{* * * *} \\
(3.46)\end{array}$ \\
\hline Wage & $\begin{array}{l}-6.25 \mathrm{E}-7 \\
(-1.08)\end{array}$ & Area & $\begin{array}{l}-1.47 \mathrm{E}-7 \\
(-1.01)\end{array}$ & $\begin{array}{l}\begin{array}{l}\text { Hospitals } \\
\text { (number) }\end{array} \\
\end{array}$ & $\begin{array}{l}1.79 \mathrm{E}-6 \\
(0.07)\end{array}$ \\
\hline R2 & 0.54 & R2 & 0.54 & R2 & 0.53 \\
\hline
\end{tabular}


Table 1c (continued)

\begin{tabular}{l|l|l|l|l|l}
\hline 10 & & & & & \\
\hline Constant & $-0.0020^{* * *}$ & & & & \\
\hline & $(-2.48)$ & & & & \\
\hline Population & $7.2 \mathrm{E}-10 * * *$ & & & & \\
\hline & $(6.1)$ & & & & \\
\hline Population density & $-2.28 \mathrm{E}-7 * *$ & & & \\
\hline G/P ratio & $0.0029 * * *$ & & & \\
\hline Poverty & $(3.36)$ & & & & \\
\hline R2 & $5.53 \mathrm{E}-9$ & & & & \\
\hline & $(0.73)$ & & & & \\
\hline
\end{tabular}

The values in () are t values (***,**, and * for $1 \%$ significance, $5 \%$ significance and $10 \%$ significance, respectively)

we estimate (2) by controlling urban and rural population and water area. Table 2a shows, however, that even if they are controlled, the negative effect of population density persists whereas urban and rural population densities and water area are insignificant for all but one specification. Another possible explanation may be that the negative correlation is due to the outlier (Miami-Dade) in the dataset. As Table $2 \mathrm{~b}$ shows, in fact, population density becomes insignificant if Miami-Dade County is excluded.

Finding 2 A higher population density leads to a fewer number per capita of COVID19 cases.

\subsection{Pandemic Suppressing Effect of Urbanization}

As is discussed above, congestion might lead people to behave more carefully against the COVID-19 outbreak, thereby negatively affecting the per capita cases. This result may be reinforced by including in estimation the degree of urbanization in a county, $K$, which is measured by the number of cities, and the augmented population by the degree of urbanization, that is, $K \cdot P$, where $K$ denotes the number of cities in a county. Equation (5) now becomes

$$
n=c+\beta_{K} K+\beta_{K P} K \cdot P+\beta_{D} D+\beta_{P} P+\beta_{o}
$$

Columns 1 through 3 of Table 3 summarizes the estimation results for various combinations of explanatory variables, population $P$ and effective population $K \cdot P$. 


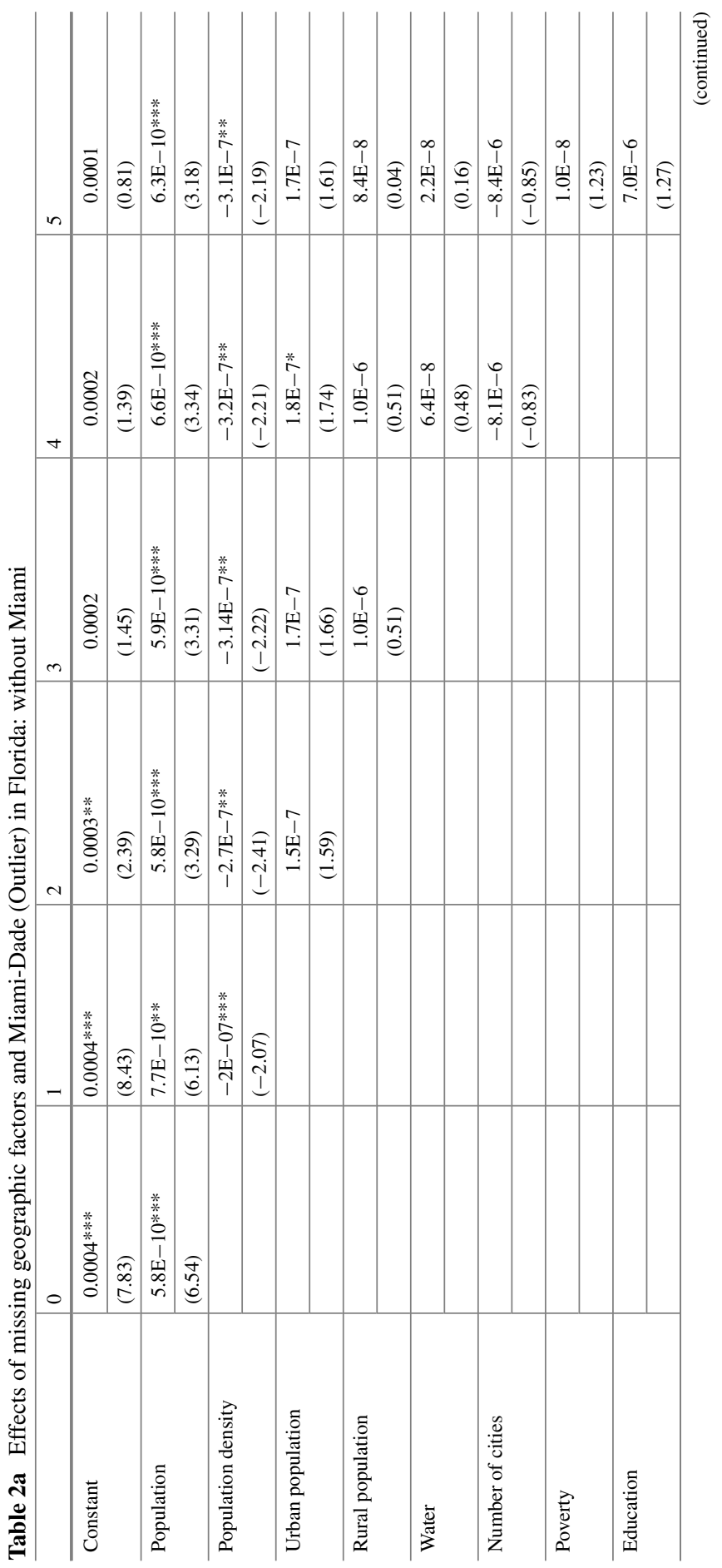




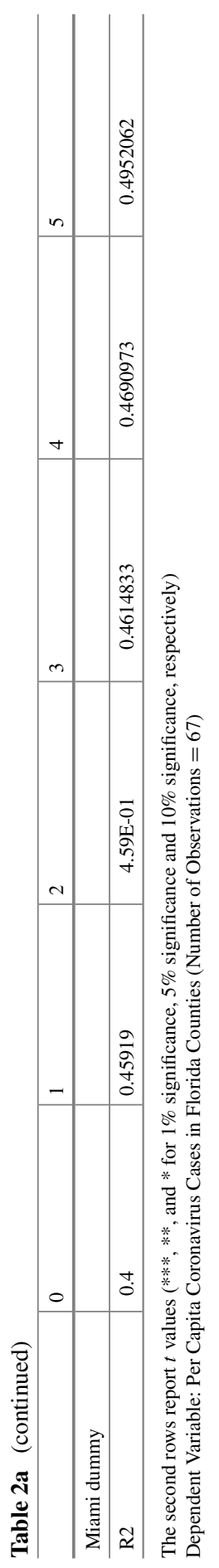


Table 2b Effects of missing geographic factors and Miami (Outlier) in Florida: With Miami

\begin{tabular}{|c|c|c|c|c|c|c|}
\hline & 6 & 7 & 8 & 9 & 10 & 11 \\
\hline \multirow[t]{2}{*}{ Constant } & $0.0004 * * *$ & $0.0005 * * *$ & $0.0004 * * *$ & $0.0003 * *$ & $0.0003 *$ & 0.0002 \\
\hline & $(8.98)$ & $(9.04)$ & $(3.01)$ & $(2.03)$ & $(1.92)$ & $(1.29)$ \\
\hline \multirow[t]{2}{*}{ Population } & $3.9 \mathrm{E}-10^{* * *}$ & $5.1 \mathrm{E}-10 * * *$ & $4.4 \mathrm{E}-10 * *$ & $4.5 \mathrm{E}-10 * *$ & $5.0 \mathrm{E}-10 * *$ & $4.1 \mathrm{E}-10 *$ \\
\hline & $(3.64)$ & $(3.15)$ & $(2.36)$ & $(2.38)$ & $(2.38)$ & $(1.92)$ \\
\hline \multirow{2}{*}{$\begin{array}{l}\text { Population } \\
\text { density }\end{array}$} & & $-1.2 \mathrm{E}-7$ & $-1.6 \mathrm{E}-7$ & $-2.0 \mathrm{E}-7$ & $-2 \mathrm{E}-7$ & $-2 \mathrm{E}-7$ \\
\hline & & $(-1.04)$ & $(-1.27)$ & $(-1.29)$ & $(-1.32)$ & $(-1.17)$ \\
\hline \multirow{2}{*}{$\begin{array}{l}\text { Urban } \\
\text { population }\end{array}$} & & & $8.5 \mathrm{E}-8$ & $9.7 \mathrm{E}-8$ & $1.1 \mathrm{E}-7$ & $6.9 \mathrm{E}-8$ \\
\hline & & & $(0.85)$ & $(0.93)$ & $(0.99)$ & $(0.64)$ \\
\hline \multirow{2}{*}{$\begin{array}{l}\text { Rural } \\
\text { population }\end{array}$} & & & & $8.6 \mathrm{E}-7 *$ & $9.4 \mathrm{E}-7$ & $-4 \mathrm{E}-7$ \\
\hline & & & & $(0.44)$ & $(0.46)$ & $(-0.18)$ \\
\hline \multirow[t]{2}{*}{ Water } & & & & & $6.3 \mathrm{E}-8$ & $-3 E-9$ \\
\hline & & & & & $(0.49)$ & $(-0.03)$ \\
\hline \multirow{2}{*}{$\begin{array}{l}\text { Number of } \\
\text { cities }\end{array}$} & & & & & $-5.5 \mathrm{E}-6$ & $-5 \mathrm{E}-6$ \\
\hline & & & & & $(-0.57)$ & $(-0.48)$ \\
\hline \multirow[t]{2}{*}{ Poverty } & & & & & & $9.8 \mathrm{E}-9$ \\
\hline & & & & & & $(1.23)$ \\
\hline \multirow[t]{2}{*}{ Education } & & & & & & $1 \mathrm{E}-5$ \\
\hline & & & & & & $(1.89)$ \\
\hline \multirow{2}{*}{$\begin{array}{l}\text { Miami } \\
\text { dummy }\end{array}$} & 0.0013 & 0.0011 & 0.0010 & 0.0010 & 0.0009 & 0.0012 \\
\hline & $(3.04)$ & $(2.40)$ & $(1.95)$ & $(1.92)$ & $(1.79)$ & $(2.25)$ \\
\hline $\mathrm{R} 2$ & 0.4756 & 0.4845 & 0.4904 & 0.4920 & 0.4965 & 0.5364 \\
\hline
\end{tabular}

The second rows report $t$ values (***,**, and * for $1 \%$ significance, 5\% significance and $10 \%$ significance, respectively)

Dependent Variable: Per Capita Coronavirus Cases in Florida Counties (Number of Observations $=67)$

In order to check multicollinearity, we report the vif values on each coefficient in double parentheses; we report only results in which the vif values are all smaller than 10 , which suggests that multicollinearity does not pose a serious problem.

The results in Table 3 show that once effective population $K \cdot P$ is included, neither population $P$ nor population density $D$ is significant any more. Columns 4 and 5 of Table 4 show that urbanization factor $K$ alone does not have a similar effect.

These results suggest that the main factors related to the number per capita of COVID-19 cases are urbanization $K$ and urbanization-adjusted population $K \cdot P$. The last model we examine, therefore, includes only these variables with other control variables. The estimation equation is.

$$
n=c+\beta_{K} K+\beta_{K P} K \cdot P+\beta_{o}[\text { control variables }]
$$




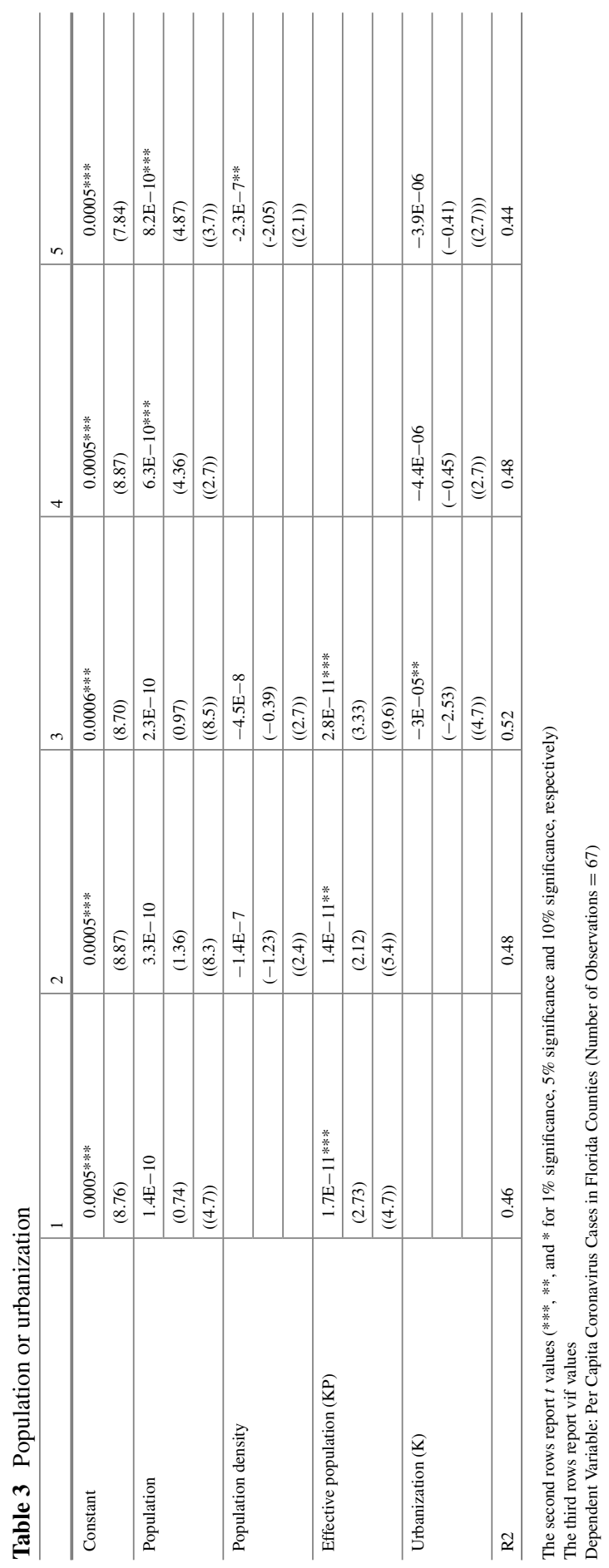


Table 4 Effects of urbanization and urbanization adjusted population

\begin{tabular}{|c|c|c|c|c|}
\hline & 1 & 2 & 3 & 4 \\
\hline \multirow[t]{2}{*}{ Constant } & 0.0005 & 0.0004 & 0.0005 & 0.0004 \\
\hline & $(4.25)$ & (3.15) & (4.18) & (3.04) \\
\hline \multirow[t]{2}{*}{ Effective population } & $3.1 \mathrm{E}-11$ & $3.6 \mathrm{E}-11$ & $3.1 \mathrm{E}-11$ & $3.4 \mathrm{E}-11$ \\
\hline & $(4.79)$ & $(5.63)$ & $(3.22)$ & (3.67) \\
\hline \multirow[t]{2}{*}{ Urbanization } & $-3.25 \mathrm{E}-05$ & $-3.872 \mathrm{E}-05$ & $-3.275 \mathrm{E}-05$ & $-3.7 \mathrm{E}-5$ \\
\hline & $(-2.91)$ & $(-3.60)$ & $(-2.32)$ & $(-2.74)$ \\
\hline \multirow[t]{2}{*}{ Water area } & $9.0 \mathrm{E}-8$ & $4.0 \mathrm{E}-8$ & $9.1 \mathrm{E}-8$ & $3.6 \mathrm{E}-8$ \\
\hline & $(0.75)$ & $(0.35)$ & $(0.75)$ & $(0.31)$ \\
\hline \multirow[t]{2}{*}{ Urban pop density } & $7.4 \mathrm{E}-8$ & $-3.8 \mathrm{E}-9$ & $7.4 \mathrm{E}-8$ & $-6.5 \mathrm{E}-9$ \\
\hline & $(0.91)$ & $(-0.05)$ & $(0.90)$ & $(-0.08)$ \\
\hline \multirow[t]{2}{*}{ Poverty } & & $1.1 \mathrm{E}-8$ & & $1.1 \mathrm{E}-8$ \\
\hline & & $(1.56)$ & & (1.53) \\
\hline \multirow[t]{2}{*}{ Education } & & $1.2 \mathrm{E}-5$ & & $1.3 \mathrm{E}-5$ \\
\hline & & (2.73) & & $(2.71)$ \\
\hline \multirow[t]{2}{*}{ Miami dummy } & & & $-1.6 \mathrm{E}-5$ & 0.0002 \\
\hline & & & $(-0.03)$ & $(0.26)$ \\
\hline $\mathrm{R} 2$ & 0.5276 & 0.5922 & 0.5276 & 0.5926 \\
\hline
\end{tabular}

The second rows report $t$ values (***,**, and * for $1 \%$ significance, $5 \%$ significance and $10 \%$ significance, respectively)

Dependent Variable: Per Capita Coronavirus Cases in Florida Counties (Number of Observations $=67)$

Table 4 summarizes estimation results. The first four columns are with all data and the second four columns are without Miami-Dade data. With or without Miami Dade County, the coefficients on effective population, urban factor (the number of cities), and education are all significant at the $1 \%$ level. The coefficient on urban factor is negative, which we may capture the preventive effect of congestion against COVID-19 infection.

In all estimations, effective population $K \cdot P$ is positively correlated to the number per capita of COVID-19 cases. In contrast, urbanization $K$ is negatively correlated to it. This suggests that those who live in a county with a high level of urbanization tend to contract COVID-19 less. This suggests that people might learn from the experience of northeastern states and make more self-protection efforts.

Finding 3 A higher urbanization leads to a fewer the number per capita of COVID-19 cases. 


\section{Determinants of the Pandemic: Political Leadership and Self-Protection}

The results summarized in Tables 3 and 4 suggest that we may replace population $P$ and population density $D$ by effective population $K \cdot P$ and urbanization factor $K$. With this consideration, we now investigate whether or not the number of coronavirus cases per capita is positively influenced by the core Trump supporters, unbanization, and urbanization adjusted population. Our estimation equation is

$$
n=c+\beta_{G P} R+\beta_{K} K+\beta_{K P} K \cdot P+\beta_{o}[\text { control variables }]
$$

Voting behaviour and self-protection behaviour against COVID-19 might be simultaneously determined by some missing variables, political beliefs, types of information that voters receive from media, among others. In order to cope with this endogeneity problem and to find a causality between the core Trump supporters and the COVID cases, we adopt the property tax of a county as an instrumental variable for the leader index. Because the property tax was determined before the COVID-19 pandemic, it is unlikely that the property tax of a county directly affects the number per capital of COVID-19 cases in the county. Thus, the property tax is a very good candidate for an instrumental variable for the leader index.

Table 5 presents an estimation result, which clears standard tests for instrumental variable estimation. As the table shows, the effects of the core Trump supporters, effective population, and urbanization are all significant; the number per capita of COVID-19 cases may be expressed as.

$$
n=-0.0043013-2.83 E^{-11}(812701-P) K+0.00570 R \text {. }
$$

This shows that an increase in the leader index leads to a higher number per capita of COVID-19 cases.

Finding 4 Political leadership matters in the fight against the COVID-19 pandemic.

Equation (9) captures the preventive effect of urbanization against COVID-19. That is, the number of per capita cases decreases with urbanization (an increase in $K$ ) among the counties with populations smaller than the cutoff value of 812701. Of the 67 Florida counties, Miami Dade County has the largest population $(2,812,130)$, followed by Broward $(1,919,644)$, Palm Beach $(1,447,857)$, Hillsborough $(1,444,870)$, Orange $(1,386,080)$, Pinnella $(978,045)$, Duval $(970,672)$, and Polk $(690,606)$. Thus, we may summarize this finding as follows:

Finding 5 Except for the seven most populated counties, the preventive effect of urbanization against COVID-19 exists; that is, the higher the degree of urbanization, the smaller the number of per capita COVID-19 cases, if other factors are kept constant. 
Table 5 Effects of urbanization and urbanization adjusted population

\begin{tabular}{|c|c|c|c|c|}
\hline & 1 & 2 & 3 & 4 \\
\hline \multirow[t]{2}{*}{ Constant } & 0.0005 & 0.0004 & 0.0005 & 0.0004 \\
\hline & $(4.25)$ & (3.15) & (4.18) & (3.04) \\
\hline \multirow[t]{2}{*}{ Effective population } & $3.1 \mathrm{E}-11$ & $3.6 \mathrm{E}-11$ & $3.1 \mathrm{E}-11$ & $3.4 \mathrm{E}-11$ \\
\hline & $(4.79)$ & $(5.63)$ & $(3.22)$ & (3.67) \\
\hline \multirow[t]{2}{*}{ Urbanization } & $-3.25 \mathrm{E}-05$ & $-3.872 \mathrm{E}-05$ & $-3.275 \mathrm{E}-05$ & $-3.7 \mathrm{E}-5$ \\
\hline & $(-2.91)$ & $(-3.60)$ & $(-2.32)$ & $(-2.74)$ \\
\hline \multirow[t]{2}{*}{ Water area } & $9.0 \mathrm{E}-8$ & $4.0 \mathrm{E}-8$ & $9.1 \mathrm{E}-8$ & $3.6 \mathrm{E}-8$ \\
\hline & $(0.75)$ & $(0.35)$ & $(0.75)$ & $(0.31)$ \\
\hline \multirow[t]{2}{*}{ Urban pop density } & $7.4 \mathrm{E}-8$ & $-3.8 \mathrm{E}-9$ & $7.4 \mathrm{E}-8$ & $-6.5 \mathrm{E}-9$ \\
\hline & $(0.91)$ & $(-0.05)$ & $(0.90)$ & $(-0.08)$ \\
\hline \multirow[t]{2}{*}{ Poverty } & & $1.1 \mathrm{E}-8$ & & $1.1 \mathrm{E}-8$ \\
\hline & & $(1.56)$ & & (1.53) \\
\hline \multirow[t]{2}{*}{ Education } & & $1.2 \mathrm{E}-5$ & & $1.3 \mathrm{E}-5$ \\
\hline & & (2.73) & & $(2.71)$ \\
\hline \multirow[t]{2}{*}{ Miami dummy } & & & $-1.6 \mathrm{E}-5$ & 0.0002 \\
\hline & & & $(-0.03)$ & $(0.26)$ \\
\hline $\mathrm{R} 2$ & 0.5276 & 0.5922 & 0.5276 & 0.5926 \\
\hline
\end{tabular}

The second rows report $t$ values (***,**, and * for $1 \%$ significance, $5 \%$ significance and $10 \%$ significance, respectively)

Dependent Variable: Per Capita Coronavirus Cases in Florida Counties (Number of Observations $=67)$

\section{Unique Environments Surrounding Florida}

Our results show the importance of political leadership, in particular national political leadership, and self-protection in the fight against COVID-19. We believe it unlikely to obtain similar results with data other than Florida; there is no other industrial state in the US that is surrounded by the sea. Because Florida is surrounded almost completely by the sea, it eliminates potential noises that may dampen the effect of political and social learning factors. Moreover, Florida happened to have the gubernatorial election in 2018 and elected a Republican governor, who strongly supports President Trump, who is also a Republican. Unless these two conditions were not met, it would have been difficult to capture our results.

In order to double check this possibility, we study Ohio by the same method. Ohio elected a Republican governor in 2018, Governor Dewine. However, Governor Dewine has maintained a distance from the president since the time of his election. ${ }^{17}$

${ }^{17}$ See Gomez (2018). 
Ohio was the first to close schools in the middle of March. ${ }^{18}$ In April 2020, it was considered to be one of the more successful states in controlling the virus. ${ }^{19}$

To check these differences matters, we make the same estimations with Florida data. The estimation results on models (1), (2) and (4) by using Ohio data show that almost no variables have significant effects; see Yano (2020, Tables 1 and 2) for details. This suggests that Florida is uniquely suited for the purpose of our study.

\section{Conclusion}

Our results show that political and demographic factors are important in determining the way in which COVID-19 spreads. In a state in which both local and national leaders downplay the danger of the virus, the number of per capita coronavirus cases increases with the number of core supporters of the national leader (Finding 4). At an early stage, the outbreak spreads in a natural manner, accelerating with population (Finding 1). Except for a handful of highly populated counties, urbanization reduces the number of per capita coronavirus cases (Finding 5). No such effects emerge in a state in which the local governor took a careful approach, as shown by Ohio data.

This result may be interpreted as follows. If both local and national leaders downplay the danger of the virus, their core supporters may be led to become less careful against the virus. At the same time, many people compensate for inadequate information and take their own self-protective measures, which may explain the preventive effect of urbanization against COVID-19 observed in most of the Florida counties (except the seven most populated counties).

Developing a cheap-talk game, Honryo and Yano (2020) show that a government can easily manipulate information if the government cares how the public perceives the government's performance. This theoretical prediction is empirically supported by our results as well as the recent work of Ajzenman et al. (2020), Bursztyn et al. (2020), and Brzezinski et al. (2020). The recent work of Blickle (2020) indicates that the future course of a society can be badly affected by a pandemic. Our result suggests the importance of transparency in the information provided by the government.

\section{References}

Adolph C, Amano K, Bree BJ, Fullman N, Wilkerson J (2020) Pandemic politics: timing state-level social distancing responses to COVID-19. medRxiv

Ajzenman N, Cavalcanti T, Da Mata D (2020) More than words: leaders' speech and risky behavior during a pandemic. CEPR DP14707

Allcott H, Boxell L, Conway J, Gentzkow M, Thaler M, Yang D (2020) Polarization and public health: partisan di erences in social distancing during COVID-19. NBER Working Paper 26946, NBER

\footnotetext{
${ }^{18}$ Camera (2020).

${ }^{19}$ It has a much smaller number of cases in comparison with some of the neighboring industrial state; for example, as of May 2, 2020, the number of cases is 19,335 in Ohio whereas it is 50,983 in Pennsylvania, 42,348 in Michigan, 56,055 in Illinois, and 18,941 in Indiana.
} 
Andersen M (2020) Early evidence on social distancing in response to COVID-19 in the United States. SSRN, downloaded at https://papers.ssrn.com/sol3/papers.cfm?abstract_id=3569368 on April 23, 2020

Barrios J, Hockberg Y (2020) Risk perception through the lens of politics in the time of the COVID19 pandemic. Becker Friedman Institute Working Paper No. 2020-32, University of Chicago

Blake A (2020) 2 months in the dark: the increasingly damning timeline of Trump's coronavirus response. Washington Post, April 22, 2020

Blickle K (2020) Pandemics change cities: municipal spending and voter extremism in Germany, 1918-1933. Staff Report No. 921, Federal Reserve Bank of New York

Brzezinski A, Kecht V, Van Dijckel D, Wright A (2020) Belief in science influences physical distancing in response to COVID-19 lockdown policies. Becker Friedman Institute for Economics Working Paper, No. 2020-56, University of Chicago

Bursztyn L, Rao A, Roth C, Yanagizawa-Drott D (2020) Misinformation during a pandemic. becker friedman institute for economics working paper 2020-44, University of Chicago

Camera L (2020) Ohio Gov. Mike DeWine Orders All K-12 schools closed: the state becomes the first to close all schools in the face of the COVID-19 outbreak. U.S. News, March 12

Fetzer T, Hensel L, Hermle J, Roth C (2020) Coronavirus perceptions and economic anxiety. arXiv preprint arXiv:2003.03848.

Gomez H (2018) Donald trump will hold an ohio rally the day before the midterms. In: The republican candidate for governor there is a maybe. BuzzFeed News, Oct 31

Honryo T, Yano M (2020) Idiosyncratic information and vague communication. Amer Political Sci Rev 115-1:165-178

Kermack W, McKendrick A (1927) A contribution to the mathematical theory of epidemics. In: Proceedings of the royal society A, pp 700-721

Luscombe R (2020) Florida's slow response: a "mini-Trump" governor who borrowed the president's playbook. Guardian, April 5, 2020

Nazaryan A (2020) How the coronavirus undid Florida Gov. Ron DeSantis. Yahoo News, May 4, 20

Sandoval H (2015) Poverty and income in Florida. University of Florida, Bureau of Economic and Business Research and Department of Economics

Sato M, Ota R, Ito A, Yano M (2020) Three minds equal Manjushari's Wisdom: an anatomy of informal social learning with heterogenous agents by the hierarchical bayesian approach. RIETI DP 20-E-092

Wright A, Sonin K, Driscoll J, Wilson J (2020) Poverty and economic dislocation reduce compliance with COVID-19 shelter-in-place protocols. Becker Friedman Institute for Economics Working Paper, 2020-40, University of Chicago

Yano M (2020) Covid-19 pandemic and politics: the cases of Florida and Ohio. RIETI DP 20-E-40

Makoto Yano is Chairman of the Research Institute of Economy, Trade and Industry (RIETI); he is also a specially appointed professor at Kyoto University and Sophia University. He is an internationally known researcher who has made a number of substantial contributions in international trade, and especially on economic dynamics. In a series of recent research, Yano proposes market quality theory, addressing various problems in modern economies, including the financial market crisis since 2008 and the recent nuclear accidents in Japan, from the point of view of market quality. Concerning quality of competition, quality of information, and quality of products, market quality is defined as an index jointly determined by the efficiency of an allocation and the fairness of the prices that are achieved in a market. An influence of his theory can be seen in Krishnendu Dastidar's book, Oligopoly, Auctions and Market Quality (2017), included in the same Springer book series as the present volume. Yano received a BA in economics from the University of Tokyo in 1971 and a PhD in economics from the University of Rochester in 1981. 
Open Access This chapter is licensed under the terms of the Creative Commons AttributionNonCommercial-NoDerivatives 4.0 International License (http://creativecommons.org/licenses/bync-nd/4.0/), which permits any noncommercial use, sharing, distribution and reproduction in any medium or format, as long as you give appropriate credit to the original author(s) and the source, provide a link to the Creative Commons license and indicate if you modified the licensed material. You do not have permission under this license to share adapted material derived from this chapter or parts of it.

The images or other third party material in this chapter are included in the chapter's Creative Commons license, unless indicated otherwise in a credit line to the material. If material is not included in the chapter's Creative Commons license and your intended use is not permitted by statutory regulation or exceeds the permitted use, you will need to obtain permission directly from the copyright holder.

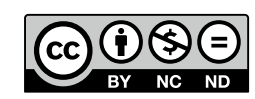

